\title{
PEMBENTUKAN PORTOFOLIO OPTIMAL MENGGUNAKAN MODEL MARKOWITZ
}

\author{
Ni Putu Eka Cahya Setyawati ${ }^{1}$ \\ Gede Merta Sudiartha ${ }^{2}$ \\ ${ }^{1,2}$ Fakultas Ekonomi dan Bisnis Universitas Udayana (Unud), Bali, Indonesia \\ ${ }^{1}$ Email : ekacahya.mei13@gmail.com
}

\begin{abstract}
ABSTRAK
Investasi merupakan aktivitas yang berkaitan dengan menanamkan sejumlah dana pada aset riil dan aset finansial seperti tanah, emas, saham, deposito, obligasi, invetasi pada pasar uang dan bentuk lainnya. Sebagai pihak yang melakukan investasi, investor akan dihadapkan pada berbagai pilihan dalam berinvestasi yang masing-masing memiliki tingkat pengembalian dan risiko yang berbeda-beda. Cara yang biasa digunakan investor dalam melakukan diversifikasi adalah melalui pembentukan portofolio. Penelitian ini dilakukan pada indeks pasar modal yaitu IDX30 periode Januari 2017-Januari 2018, khususnya pada sektor pertambangan dan barang konsumsi.Penelitia dilakukan untuk membentuk sebuha kombinasi aset saham menjadi sebuah portfolio optimal serta besaran proporsi dana dari masing-masing saham yang terbentuk menggunakan models Markowitz. Hasil penelitian menunjukkan dari empat belas sampel saham, terpilih tujuh saham yang berhasil menjadi kandidat portfolio optimal bentukan model Markowitz. Tujuh buah saham dengan proporsi alokasi dana masing-masing yaitu saham ADRO (0,55\%), ASII (0,15\%), GGRM (17,61\%), ICBP (9,46\%), MEDC (5,275), UNVR (41,11\%), dan UNTR (25,86\%), dengan menghasilkan expected return sebesar 3,2\% dan dengan tingkat risiko sebesar 3,3\%.

Kata Kunci: portofolio optimal, model Markowitz, sektor pertambangan dan barang konsumsi
\end{abstract}

\begin{abstract}
Investment can be related to investing some funds in financial assets or real assets such as land, gold, shares, deposits, bonds and other forms. As a party who is make an investment, investors will be faced with a variety of options in investing that has a rate of return and riskappropriate expectations. The ways that usually used by investors is to diversify through the creation of a portfolio. The aim of this research is to know the stocks that can be inserted into the optimal portofolio as well as the proportions of each of the stocks, that the model established by Markowitz. This research was conducted on the IDX30 index from January 2017 to January 2018, especially in the mining sector and consumer goods. The results showed, from 14 stock, 7 stock was selected as candidate of portfolio optimal Markowitz models. Stocks that are worth being a member of the optimal portfolio by a proportion of the allocation of each fund i.e. stocks ADRO (0.55\%), ASII (0.15\%), GGRM (17.61\%), ICBP (9.46\%), MEDC (5.275), UNVR (41.11\%), and UNTR (25.86\%), it gives the expected portfolio return of $3.2 \%$ and with the level of risk of $3.3 \%$.
\end{abstract}

Keywords: optimal portfolio, Markowitz model, mining sector and consumer goods 
Ni Putu Eka Cahya Setyawati, Pembentukan Portofolio Optimal...

\section{PENDAHULUAN}

Investasi merupakan aktivitas yang berkaitan dengan menanamkan sejumlah dana pada aset riil maupun aset finansial seperti tanah, emas, saham, deposito, obligasi serta bentuk lainnya. Kesadaran masyarakat dalam berinvestasi semakin meningkat, selain menabung pada bank, alternatif lain investasi misalnya berinvestasi pada saham, reksadana, investasi pada pasar uang dan lain sebagainya. Pilihan berinvestasi tidak hanya bergantung pada tingkat keuntungan yang diharapkan melainkan juga pada besarnya risiko yang mungkin dihadapi. Seorang investor akan dihadapkan pada berbagai investasi yang memiliki return dan risiko yang berbeda-beda. Hal ini mengharuskan investor untuk mampu membuat analisis investasi sebelum menanamkan dananya (Nalini, 2014).

Tingginya tingkat risiko yang akan dihadapi investor, menyebabkan investor harus mengambil langkah antisipasi salah satunya yaitu melalui diversifikasi. Diversifikasi pada risiko tidak sistematis dilakukan lewat pembentukan portofolio. Pentingnya pembentukan portofolio adalah untuk memaksimalkan fungsi dan nilai suatu aset agar memeroleh keuntungan lebih besar dengan tingkat risiko tertentu, atau memeroleh keuntungan tertentu dengan tingkat risiko paling minimal (Lee et al. 2015). Salah satu alat analisa yang biasanya digunakan para peneliti untuk melakukan analisis portofolio adalah model Markowitz (Aj Du dan Ward, 2009).

Hasil temuan Pracanda (2017) menjelaskan bahwa saham-saham yang dibentuk menjadi portfolio optimal dengan Model Markowitz adalah enam buah saham pada Indeks pasar modal IDX 30 periode Agustus 2017 hingga Juli 2016 dengan masing-masing proporsi dana optimal untuk saham ADHI (9.57\% ), BBCA 
(28.92\%) LPKR (6.20\%), SCMA (18.99\%), TLKM (25.38\%) dan UNVR $(10.94 \%)$.

Ivanova (2017) melakukan penelitian tentang pengaplikasian dari Markowitz dalam membentuk portofolio optimal di pasar saham Bulgarian periode 2013-2016, dari 50 saham terpilih 27 kandidat saham yang dimasukkan ke dalam portofolio optimal dengan besar masing-masing proporsi dana yaitu saham $\operatorname{BIOV}(1,14 \%)$, HVAR (3.52\%), ELHIM (0.95\%), E4AP (0.82\%), ALUM (7.17\%), CENHIL (11.11\%), FZLES (0.87\%), FPP (3.56\%), OSP (6.96\%), HES(7.81\%), AGR (11.96\%), MCH (7.39\%), BREF (3.67\%), HNVEK (4.90\%), MOMKR (1.46\%), ERH (1.44\%), ODES (2.89\%), KRS (2.72\%), ZAHZA (1.89\%), LAVEN (2.20\%), AROMA (1.70\%), ROZA (5.71\%), ELTOS (1.09\%), TODOROF (2.12\%), FEEI (1.49\%), ERGC3 (1.46\%), dan UPAC (2.00\%).

Peneliti memilih sektor pertambangan dan sektor barang konsumsi, alasan dipilihnya kedua sektor tersebut adalah sektor -sektor ini memiliki tingkat korelasi negative. Kedua sektor berkorelasi negatif asumsinya bahwa perusahaanperusahaan dari sektor tersebut memiliki market share atau pangsa pasar yang berbeda. Perusahaan yang tergabung dalam sektor pertambangan menggantungkan penjualannya pada produksi komoditas ekspor dan transaksi perdagangan pada pasar global. Pergerakan harga saham sektor ini bergantung pada volatilitas harga minyak mentah dunia. Perusahaan dari sektor barang konsumsi menggantungkan penjualan hasil produknya pada konsumsi, daya beli dan selera masyarakat. Pergerakan harga saham sektor ini bergantung pada kuat lemahnya nilai rupiah dan inflasi. Apabila rupiah cenderung melemah, maka akan berdampak pada penurunan 
Ni Putu Eka Cahya Setyawati, Pembentukan Portofolio Optimal...

penjualan pada perusahaan sektor barang konsumsi, sedangkan perusahaan sektor pertambangan tidak terlalu terkena dampaknya, justru akan lebih menguntungkan eksportir dan meningkatkan hasil yang diterima karena naiknya harga tambang.

Penelitian kali ini menggunakan model Markowitz ,berbeda dengan penelitian lainnya yang umumnya menggunakan Model Indeks Tunggal dalam membangun sebuah portofolio, selain itu dipilihnya Model Markowitz karena model ini lebih terperinci dan lengkap. Peneliti ini meneliti kelompok sahamsaham apa saja yang menjadi anggota portfolio optimal serta berapa bobot dana masing-masing saham. Penelitian bertujuan untuk membentuk sebuah portfolio optimal dan besarnya porsi dana yang diinvestasikan masing-masing saham, serta expected return dan risiko yang dihasilkan..

Investasi sering diartikan sebagai kegiatan menanamkan dana yang dimiliki sekarang dengan ekspetasi akan ada keuntungan yang diperoleh dimasa mendatang. Tandelilin (2010:102) mengemukakan bahwa return merupakan bentuk pengembalian yang diterima investor atas keberaniannya menanggung risiko investasi. Serta merupakan salah satu faktor yang memotivasi investor untuk terus berinvestasi . Jika investor membeli saham, yield adalah besarnya dividen yang dibagikan kepada investor, namun apabila perusahaan mengambil kebijakan tidak membagi dividen tersebut maka dividen ini akan menjadi laba ditahan yang digunakan untuk investasi selanjutnya. Komponen kedua dari return adalah capital gain/capital loss, yaitu kenaikan atau penurunan harga surat berharga.

Berbagai risiko yang timbul akibat berinvestasi selalu berusaha diminimalkan oleh investor. Risiko investasi terjadi ketika terdapat perbedaan antara tingkat 
pengembalian yang sesungguhnya dengan tingkat pengembalian yang diharapkan oleh investor . Tandelilin (2010:103), membagi risiko menjadi beberapa sumber yang memengaruhi besarnya investasi, yaitu risiko inflasi, risiko suku bunga, risiko likuiditas, risiko pasar, risiko mata uang, dan risiko bisnis.

Investasi terdiri dari risiko sistematis (risiko pasar) dan risiko tidak sistematis (risiko manajemen). Diversifikasi merupakankegiatan membentuk suatu portfolio, didalam portofolio tersebut terdapat berbagai jenis investasi sehingga risiko dari portofolio dapat berkurang.Portofolio adalah kumpulan atau kombinasi berbagai sekuritas yang dibentuk sedemikian rupa hingga dapat mencapai tujuan investor. Teori portoflio model Markowitz didasari beberapa asumsi, yaitu : Periode melakukan investasi tunggal, misalnya satu tahun, biaya transaksi ditiadakan, investor mendasarkan preferensinya terhadap return harapan dan risiko, tidak terdapat pinjaman dan simpanan bebas risiko.

Chandra, Liliana dan Hapsari (2013) melakukan penelitian terkait pembentukan portofolio optimal menggunakan model Markowitz portofolio terdiri dari saham ASII (0.80\%), BBCA (15.90\%), BBNI (6.6\%),BBRI (9.20\%),BDMN (2.3\%), BMRI (10.1\%),INDF (8.3\%),ISAT (2.8\%) ,PGAS (1.8\%) PTBA (5.3\%), TINS (0.9\%), TLKM (9.5\%), UNVR (25.4\%). dan AALI (1.10\%.)

Rahmat dan Nugroho (2013) melakukan penelitian dengan menggunakan model Markowitz, terpilih 5 saham yaitu GTBO, SSIA, CMNP, LPPS, LPLI kemudian terbentuk 3 buah kombinasi portofolio. Perhitungan pada penelitian ini menggunakan Markowitz Efficient Frontier Theory. Portofolio pertama merupakan kombinasi portofolio dengan proporsi dana sama yaitu sebesar $20 \%$ dengan return 
Ni Putu Eka Cahya Setyawati, Pembentukan Portofolio Optimal...

sebesar $0,29 \%$, risiko sebesar $1.78 \%$, rasio Sharpe sebesar $16.11 \%$, rasio Treynor 0,21\%, dan rasio Jensen sebesar $0,26 \%$. Portofolio kedua adalah kombinasi portofolio dengan return maksimal, dengan alokasi dana pada saham GTBO 33\%, SSIA 18\%, CMNP 27\%, LPPS 15\%, dan LPLI 7\%, menghasilkan return sebesar 0,39\%, risiko 2,01\%, rasio Sharpe $19,59 \%$, rasio Treynor $0,60 \%$, dan rasio Jensen 0,39\%. Portofolio ketiga merupakan portofolio yang dibentuk berdasarkan standar deviasi terkecil, dialokasian pada saham GTBO 7\%, SSIA 15\%, CMNP 50\%, LPPS 18\%, dan LPLI 9\%, menghasilkan return sebesar $0,15 \%$, risiko $1,45 \%$, rasio Sharpe $10,58 \%$, rasio Treynor $0,59 \%$, dan rasio Jensen $0,15 \%$.

Penelitian yang dilakukan Abdurrazzak (2017) pada saham yang terdaftar diJakarta Composite Index periode Januari 2015-Desember 2015. Hasil penelitian menunjukkan dari 6 saham yang diteliti, terbentuk 15 kombinasi portofolio (masing-masing terdiri dari 2 saham) dengan bobot (80\%: 20\%) dan (50\%: 50\%). Terdapat satu portofolio optimal yaitu portofolio ke-6 kombinasi antar Asuransi Bina Arta Tbk. (ABDA.JK) dan Asuransi Dayin Mitra Tbk. (ASDM.JK). , yaitu (bobot $80 \%$ : 20\%) dengan tingkat keuntungan 2.359\% dan risiko $2.359 \%$. Portfolio dengan proporsi dana (bobot 50\% : 50\%) memberikan keuntungan sebesar 2.207\% dan risiko sebesar 2.207\%.Penelitian oleh Marasovic et al. (2011) pada 15 saham yang banyak diperdagangkan di pasar modal Kroasia pada 1 September 2007-1 September 2009. Penelitian ini mengungkapkan bahwa metode analisis fundamental dan teknik saling melengkapi dan mengkonfirmasi satu sama lain. Untuk tujuan pemilihan saham dalam suatu portofolio, penting untuk memulai dengan analisis fundamental. 
Setiawan (2015) melakukan penelitian pada 4 perusahaan ternama yaitu PT. Asuransi Jasaa Tania Tbk, PT. Asuransi Multhi Artha Ghuna Tbk , PT. Asuransi Ramhayana Tbk, dan PT. Asuransi Multi Artha Guna Jaya Tbk. Terbentuk 8 portofolio, dengan dua kombinasi proporsi dana. Portofolio yang dibandingkan adalah portofolio ASRM dan ASJT dengan portofolio AHAP dan ASJT. Portfolio ASRM dan ASJT memberikan keuntungan 1,14 kali dari portofolio AHAP dan ASJT. Tingkat risiko portfolio ASRM dan ASJT adalah 1,03 kali dari portfolio AHAP dan ASJT. Sehingga investasi yang dapat dipilih investor adalah portofolio ASRM dan ASJT. Sudiman dan Elsa Novyana (2016) melakukan penelitian perhitungan pada saham yang tercatat di sembilan sektor perusahaan Bursa Efek Indonesia tahun 2016. Perhitungan saham individu sebanyak 45 perusahaan, saham yang tidak pernah menjadi kandidat portofolio selama tahun 2014 adalah saham Unilever Tbk. (UNVR), dan saham yang selalu muncul menjadi kandidat portofolio adalah saham Bayan Resources Tbk. (BYAN). Model Markowitz yang diterapkan pada penelitian ini memberikan keuntungan rata-rata pengembalian sebesar 2,67\% lebih tinggi dari return IHSG yaitu hanya sebesar 1,58\%.

Parmar et al. (2014) melakukan penelitian yang menggunakan model Markowitz dan memilih empat sektor utama di India yaitu perbankan, IT, Infrastruktur dan Mobile Auto. Peneliti menemukan bahwa koefisien korelasi antar sektor memiliki varians yang tinggi disebabkan fluktuasi pasar yang tinggi dengan kinerja industri. Hasil ini seharusnya memberikan return positif dengan meminimalkan total risiko portofolio. Berdasarkan penelitian tidak ada perbedaan yang signifikan pada pemilihan portfolio. 
Ni Putu Eka Cahya Setyawati, Pembentukan Portofolio Optimal...

Penelitian yang dilakukan oleh Kamil dkk. (2006), tentang portofolio yang mengatur 15 saham terpilih yang diperjualberlikan diBursa Efek Kuala Lumpur (KLSE). Berdasarkan penelitian, investasi yang disarankan menggunakan sahamsaham AMMB, NESTLE dan CASRLBERG. AMMB dan NESTLE berpotensi sebagai saham untuk investor yang ingin membentuk portofolio dengan pajak. Hasil mengimplikasikan bahwa AMMB memiliki potensi untuk diinvestasikan dan hanya beberapa saham, seperti AFFIN, BAT, TANJONG, PUBLIK dan CARLSBERG yang akan dipertimbangkan dalam investasi.

Ramadhan et al. (2014) melakukan penelitian terkait model Mean Variance (MV), Mean Absolute Deviations (MAD), Downside Deviation (DD), pada Indeks pasar modal BISNIS 27 diBursa Efek Indonesia periode 2011 hingga 2013. Dari 27 saham, terpilih 10 saham sebagai sampel penelitian. Hasil penelitian ini menjelaskan bahwa Model Mean Absolute Deviations memiliki tingkat pengembalian 4,045 \%, model ini cocok untuk investor risk seeker. DD atau Downside Deviation merupakan model portofolio optimal yang cocok untuk investor dengan preferensi risk averse. Tingkat risiko yang ditawarkan sebesar $0,032 \%$.

Makwe et al. (2016) melakukan penelitian perbandingan metode diversifikasi naif (acak) dengan Markowitz. Total sampel terdiri dari 110 saham yang terdaftar di NEPSE. Berdasarkan penelitian, tidak terdapat perbedaan yang signifikan antara return, risiko portofolio, dan kinerja portfolio yang didiversifikasi secara Naif maupun Markowitz. 
Gogajeh et al. (2015) melakukan penelitian untuk membandingkan model Markowitz, Single IndexModel Sharpe, Data Envelopment Analysis(DEA) dan value at risk model (VAR) dalam memilih portofolio optimal saham di Bursa Efek Teheran yang menyimpulkan bahwa VAR dan model Sharpe memiliki kemampuan membentuk portofolio optimal di Bursa Efek Tehran sedangkan model DEA tidak.

Saranya et al. (2014) mengembangkan portfolio teori Markowitz (meanvariance) dengan menambahkan momen yang lebih tinggi seperti Skewness (saat ketiga terhadap mean) dan Kurtosis (saat keempat terhadap mean) dalam karakteristik return. Sampel terdiri dari 200 saham yang terdapat dalam Bombay Stock Exchange (BSE). Dari penelitian disimpulkan bahwa bukan hanya varians risiko yang harus dipertimbangkan saat membangun portofolio.

Penelitian yang dilakukan oleh AJ Du Plesis dan Wards (2009) terkait penerapan teori Markowitz diBursa Efek Johannesburg (JSE), penelitian untuk menentukan apakah portofolio optimal dapat diidentifikasi dan digunakan sebagai aturan perdagangan yang efektif. Total sampel terdiri dari 109 perusahaan dalam daftar mingguan Top 40, JSE.

Ferinando et al. (2006) menguji sampel yang terdiri dari 30 saham terdaftar di Bursa Efek Nepal (NEPSE). Terdapat banyak pilihan untuk membuat keputusan memilih portofolio yang optimal sesuai dengan keinginan investor . Penerapan model-model dasar dikembangkan sekitar setengah abad lalu menawarkan pilihan yang lebih baik untuk membuat keputusan dalam memilih portofolio yang optimal di pasar saham Nepal. 
Ni Putu Eka Cahya Setyawati, Pembentukan Portofolio Optimal...

Bekhet dan Mathars (2012) melakukan penelitian dengan total sampel terdiri dari 115 saham yang tecatat diBursa Efek Amman (ASE). Hasil dari penelitian menunjukan Model Indeks Tunggal dengan model Markowitz tidak memiliki perbedaan untuk portofolio yang terbentuk. Jumlah saham dalam portofolio yang dibentuk tidak cukup mempengaruhi hasil dari membandingkan dua model pilihan portfolio.

Indrayanti dan Darmayanti (2013) melakukan penelitian di BEI periode Juli 2011 hingga Juli 2012. 30 saham perbankan yang menjadi populasi dalam penelitian ini, hanya 15 saham yang masuk kriteria sebagai sampel. Penelitian ini menyimpulkan bahwa terdapat portfolio terbentuk menggunakan Model Markowitz, yang mana terdiri dari 5 saham, yaitu saham PT. Bank Negara Indonesia (Persero) Tbk, PT. Bank Of India Indonesia Tbk, PT. Bank Pundi Indonesia Tbk, PT. Bank Mayapada Internasional Tbk, dan PT. Bank Tabungan Pensiunan Nasional Tbk.

Penelitian yang dilakukan oleh Chasanah et al. (2017) ditemukan bahwa pada pembentukan portofolio saham-saham yang terdaftar di IndeksJII periode Desember 2017 hingga November 2016, terdapat perbedaan kinerja portofolio optimal bila diuji dengan Markowitz dan Model Indeks Tunggal, dimana dengan tingkat return yang sama 1,2939\%, tetapi model markowitz memiliki tingkat risiko yang lebih kecil, hal ini mengindikasikan formasi portofolio optimal dengan Model Markowitz lebih dominan daripada Model Indeks Tunggal.

Yuwono dan ramdani (2017), dipenelitian ini membentuk portofolio optimal dari saham yang tercatat di Indeks Syariah Jakarta periode 2010-2016, anatar kedua 
model analisa, ditemukan tidak ada perbedaan yang signifikan dari perhitungan portofolio yang diperoleh dengan menggunakan model indeks tunggal dibandingkan dengan model markowitz.

Martin et al. (2015), melakukan penelitian diIndeks Dow Jones Industrial Average (DJIA) dengan menggunakan Markowitz Portofolio Teori (MPT).Hasil penelitian mengungkap lima portofolio yang terbentuk, portofolio 1 tingkat return $14,20 \%$ dan standar deviasi $0,87 \%$, portofolio kedua dengan tingkat return sebesar $15,63 \%$ dan standar deviasi $1,20 \%$, portofolio ke-3 tingkat return $12,60 \%$ dengan standar deviasi $1,46 \%$, portofolio ke-4 dengan return $13,62 \%$ dan standar deviasi sebesar $0,92 \%$, serta portofolio ke-5 dengan return $12,76 \%$ dan standar deviasi 0,89\%. Hasil mengungkapkan bahwa portofolio 1 (satu) yang merupakan portofolio optimal dengan tingkat pengembalian sebesar 14,20\% dan dengan besaran risiko $0,87 \%$, hal ini sudah sesuai dengan harapan dan preferensi investor.

Penelitian Yunita (2018) terkait saham-saham yang tercatat diJakarta Islamic Index (JII) tahun 2018 yang membentuk portofolio optimal berdasarkan model Markowitz antara lain: saham AKRA (3.4\%), saham TPIA (1\%), saham ADRO (3.3\%), saham ICBP (4.7\%), sahamINCO (2.6\%), sahamMYRX (13.6\%), PTPP (4.9\% ), UNVR (39.5\%), PWON (11.3\%), UNTR (15.7\%) dan sedangkan BPRT, PTBA dan WSKT tidak termasuk ke dalam portofolio optimal. Dari hasil solver didapatkan nilai pengembalian portofolio sebesar $1.22 \%$ dan risiko portofolio adalah sebesar $0.0312 \%$. Risiko portfolio di bawah risiko masing-masing saham individual. 
Ni Putu Eka Cahya Setyawati, Pembentukan Portofolio Optimal...

Natalia (2012) melakukan penelitian tentang pembentukan portofolio optimal pada saham di Bursa Efek Indonesia tahun 2012, sampel penelitian yang menjadi anggota portofolio optimal yaitu saham perusahaan sektor Food and Beverages yang berjumlah 9 perusahaan. Alokasi dana masing-masing saham yaitu saham AISA $2,86 \%$, DLTA $16,20 \%$, ICBP $8,34 \%$, INDF 14,21\%, MLBI 6,86\%, MYOR 8,10\%, ROTI 5,72\%, SKLT 31,33\% dan ULTJ 6,39\%, menghasilkan return sebesar $0,95 \%$ dan risiko $1,29 \%$.

Rodrigues dan Suresha (2018) meneliti saham-saham yang terdaftar pada National Stock Exchange (NSE) dan NIFTY50 pada bulan April 2016-Maret 2017, sampel pada penelitian yaitu masing-masing 5 perusahaan yang termasuk ke dalam 5 sektor yaitu Banking, Pharmaceuticals, Oil and Gas, IT, dan Automotive, total sampel sebanyak 25 perusahaan. Hasil menunjukkan bahwa besar tingkat return dan risiko masing-masing sektor yaitu sektor IT return sebesar $-3,41 \%$ risiko $64,7 \%$, sektor Banking dengan return sebesar $23,76 \%$ risiko $94,38 \%$, sektor Automotive return sebesar 21,69\% risiko 130,23\%, sektor Oil and Gas return sebesar 4,48\% risiko 79,64\%, dan sektor Pharmaceuticals return sebesar $-5,15 \%$ risiko $87,78 \%$.

Sarker (2013) melakukan penelitian terhadap 164 saham yang terdaftar di Dhaka Stock Exchange (DSE) pada Juli 2007 hingga Juni 2012. Dari 164 sampel terpilih 20 saham perusahaan menjadi portofolio optimal dengan masing-masing proporsi dana saham BATBC 19,35\%, Bata Shoe 18,57\%, Fine Foods Limited 14,34\%, Lamkabangia 13,96\%, Metro Spinning 5,4\%, Beach Hatchery 5,1\%, Janata Insurance 4,4\%, Pharma Aids 4,11\%, Power Grid Company 2,92\%, Padma 
Oil Co 2,58\%, IDLC 2,37\%, Al-Haj Textile 1,52\%, CMC Kamal 1,40\%, Meghna Pet 1,13\%, City Bank 0,71\%, IFIC Bank 0,71\%, Islami Bank 0,71\%, Prime Finance 0,36\%, Bd. Welding 0,24\%, Fu-Wang Ceramic 0,001\%. Portofolio menghasilkan return sebesar $6,48 \%$ dan risiko sebesar $11,79 \%$.

Wijayanto (2015) melakukan penelitian terhadap saham-saham Indeks IDX30, dengan sampel perusahaan sebanyak 15 saham. Hasil penelitian mengungkapkan bahwa 7 buah saham terpilih menjadi anggota portofolio. Saham dan proporsi dananya masing-masing sebagai berikut, saham UNVR (31,19\%), BBCA (16,69\%), ADRO (14,14\%), UNTR (13,43\%), PGAS(9,33\%), INDF (7,73\%), dan GGRM (7,50\%).

\section{METODE PENELITIAN}

Penelitian ini menggunakan pendekatan kuantitatif dengan bentuk deskriptif, penelitian deskriptif yaitu penelitian dengan tujuan menjelaskan suatu objek yang mana dalam penelitian tersebut terdapat beberapa variabel, tanpa menghubungkan satu variabel ke variabel lainnya. Lokasi penelitian dilakukan pada perusahaanperusahaan sektor pertambangan dan sektor barang konsumsi yang terdaftar di Indeks IDX 30 pada periode Januari 2017-Januari 2018. Portofolio dibentuk dengan model Markowitz, data pada penelitian ini bersumber dari situs resmi www.investing.com dan www.idx.co.id.

Tahap awal dalam pembentukan portofolio yaitu mengumpulkan data harga penutupan masing-masing saham. Tahap selanjutnya yaitu menghitung return masing-masing sampel dengan rumus ( Hartono, 2016:284 ) : 


$$
R_{i t}=\frac{\mathrm{P}_{\mathrm{it}}-\mathrm{P}_{\mathrm{it}_{-1}}}{\mathrm{P}_{\mathrm{it}_{-1}}}
$$

Keterangan :

$\mathrm{R}_{\mathrm{it}} \quad=$ Return saham $\mathrm{i}$ pada periode $\mathrm{t}$

$\mathrm{P}_{\mathrm{it}} \quad=$ Harga saham $\mathrm{i}$ pada periode $\mathrm{t}$

$\mathrm{P}_{\mathrm{it}-1} \quad=$ Harga saham $\mathrm{i}$ pada periode $\mathrm{t}-1$

Tahap selanjutnya yaitu tahap ketiga, menghitung expected return dari masing-masing saham perusaaan sampel, persamaan atau rumus untuk menghitung expected return sebagai berikut (Hartono, 2016:117) :

$\mathrm{E}\left(\mathrm{R}_{\mathrm{i}}\right)=\frac{\sum_{i=1}^{n} R_{i t}}{n}$

Keterangan:

$\mathrm{E}\left(\mathrm{R}_{\mathrm{i}}\right)=$ Return yang diharapkan pada saham $\mathrm{i}$

$\mathrm{R}_{\mathrm{i}} \quad=$ Return pada saham i yang mungkin terjadi

$\mathrm{n} \quad=$ Jumlah periode pengamatan

Menghitung risiko saham adalah tahap keempat, perhitungan dengan standar deviasi, adapun rumus untuk menghitung risiko saham sebagai berikut (Hartono, 2016:307) :

$\mathrm{SD}=\sqrt{\sum_{t=1}^{n} \frac{\left[R_{i t}-E\left(R_{i}\right)\right]^{2}}{n}}$

Keterangan:

$\mathrm{SD}=$ Standar deviasi

$\mathrm{R}_{\text {it }} \quad=$ nilai saham ke- $\mathrm{i}$

$\mathrm{E}\left(\mathrm{R}_{\mathrm{i})}=\right.$ nilai Expected return saham ke- $\mathrm{i}$

$\mathrm{n} \quad=$ jumlah dari observasi data historis untuk sampel besar dengan $\mathrm{n}$ (paling sedikit 30 observasi) dan untuk sampel kecil menggunakan (n-1)

Menghitung kovarian antar saham merupakan tahap kelima guna mengetahui kecenderungan antar saham bergerak secara bersamaan. Untuk Kovarian dihitung dengan rumus (Hartono, 2017:340) :

$\sigma_{\mathrm{RA}, \mathrm{RB}}=\sum_{i=1}^{n} \frac{\left[\left(\mathrm{R}_{\mathrm{Ai}}-E\left(R_{A}\right)\right) \cdot\left(R_{B i}-E\left(R_{b}\right)\right)\right.}{n}$ 
Keterangan:

$\sigma_{\mathrm{RA}, \mathrm{RB}}=$ Kovarian returnantara saham A dan saham B

$\mathrm{R}_{\mathrm{Ai}} \quad=$ Return saham A pada periode $\mathrm{t}$

$\mathrm{R}_{\mathrm{Bi}} \quad=$ Return saham $\mathrm{B}$ pada periode $\mathrm{t}$

$\mathrm{E}\left(\mathrm{R}_{\mathrm{A}}\right) \quad=$ Expected return saham $\mathrm{A}$

$\mathrm{E}\left(\mathrm{R}_{\mathrm{B}}\right) \quad=$ Expected return saham $\mathrm{B}$

$\mathrm{n}=$ Jumlah observasi data historis untuk sampel besar (minimal 30 observasi) dan untuk sampel kecil digunakan (n-1)

Tahap keenam yaitu menghitung koefisien korelasi antar saham untuk mengukur seberapa besar hubungan antar saham, koefisien korelasi dapat dihitung menggunakan rumus ( Hartono, 2016:322 ) :

$r_{A B}=\rho_{A B}=\frac{\operatorname{Cov}\left(R_{A}, R_{B}\right)}{\sigma_{A}, \sigma_{B}}$

Keterangan:

$\mathrm{R}_{\mathrm{A}, \mathrm{B}} \quad=$ Koefisien Korelasi return saham A dan B

$\operatorname{Cov}\left(\mathrm{R}_{\mathrm{A}} \mathrm{R}_{\mathrm{B}}\right) \quad=$ nilai kovarian saham

$\sigma_{\mathrm{A}} \quad=$ standar deviasi $\mathrm{A}$

$\sigma_{\mathrm{B}} \quad=$ standar deviasi $\mathrm{B}$

Tahap ketujuh adalah menghitung expected return portofolio yang sudah terbentuk dengan rumus ( Hartono (2016:332 ):

$\mathrm{E}\left(\mathrm{R}_{\mathrm{p}}\right)=\sum_{i=1}^{\mathrm{n}} \mathrm{W}_{\mathrm{i}} \mathrm{E}\left(\mathrm{R}_{\mathrm{i}}\right)$

Keterangan:

$\mathrm{E}\left(\mathrm{R}_{\mathrm{p}}\right)=$ Return ekspektasi dari portofolio

$\mathrm{E}\left(\mathrm{R}_{\mathrm{i})} \quad=\right.$ Return yang diharapkan dari saham $\mathrm{i}$

$\mathrm{W}_{\mathrm{i}} \quad=$ Porsi dari saham I terhadap seluruh saham di portofolio

$\mathrm{n} \quad=$ jumlah saham yang ada dalam portofolio

Tahap kedelapan menghitung risiko portfolio, perhitungan menggunakan standar deviasi yang dipadukan dengan nilai kovarian untuk menghitung kecenderungan pergerakan saham secara bersamaan ( Hartono (2016:352) risiko portofolio dapat dihitung dengan rumus: 
$\sigma_{\mathrm{p}}=\sqrt{\sum_{i=1}^{n} \sum_{j=1}^{n} \mathrm{~W}_{\mathrm{i}} \mathrm{W}_{\mathrm{j}} \sigma_{\mathrm{ij}}}$

Keterangan:

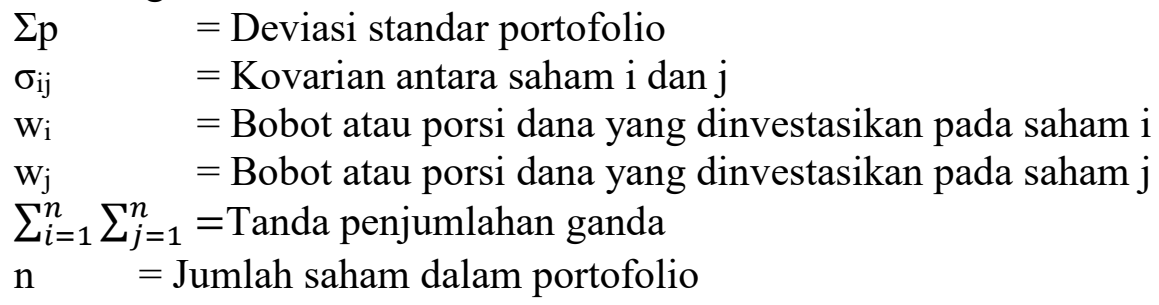

Tahap kesembilan yaitu perhitungan bobot atau proporsi optimal dengan program Solver. Tujuan program Solver adalah untuk menghitung berapa pembagian besar bobot atau proporsi dana yang optimal darimasing-masing saham dalam setiap portofolio. Setelah melakukan perhitungan program Solver, selanjutnya tahap terakhir yaitu menghitung Expected Return dan standar deviasi portofolio optimal, perhitungan ini menggunakan rumus sebagai berikut (Hartono, 2016:395).

$\sigma_{p}=\sum_{i=1}^{n} W_{i} \sigma_{i}^{2}+2 \sum_{i=1}^{n} \sum_{j=1}^{n} W_{i} W_{j} \sigma_{i j}$

Keterangan :

$\sigma_{\mathrm{p}} \quad=$ Standar deviasi portofolio

$\mathrm{W}_{\mathrm{i}} \quad=$ Bobot atau proporsi dana yang dinvestasikan pada saham $\mathrm{i}$

$\sum_{i=1}^{n} \sum_{j=1}^{n}=$ Tanda penjumlahan ganda

$\mathrm{n} \quad=$ Jumlah saham dalam portofolio

\section{HASIL DAN PEMBAHASAN}

Saham-saham yang sudah dialokasikan akan memberikan gambaran return ekspetasian baik yang bernilai positif ataupun negatif. Saham dengan expected return positif akan menjadi kandidat dari portofolio optimal, sedangkan saham dengan nilai expected return negatif akan dikeluarkan dari pembentukan. Adapun hasil dari perhitungan tahap kedua dipaparkan pada tabel berikut ini: 
Tabel 1.

Expected Return masing-masing Saham

\begin{tabular}{ccccc}
\hline No & Saham & $\mathbf{\Sigma R}_{\mathbf{i t}}$ & $\mathbf{E}\left(\mathbf{R}_{\mathbf{i}}\right)$ & $\mathbf{E}\left(\mathbf{R}_{\mathbf{i}}\right) \mathbf{( \% )}$ \\
\hline 1 & ADRO & 49,03 & 0,0377 & 3,77 \\
2 & ANTM & 8,56 & 0,0066 & 0,66 \\
3 & ASII & 10,97 & 0,0084 & 0,84 \\
4 & GGRM & 24,87 & 0,0191 & 1,91 \\
5 & HMSP & 26,20 & 0,0202 & 2,02 \\
6 & INDF & 1,73 & 0,0013 & 0,13 \\
7 & ICBP & 1,98 & 0,0015 & 0,15 \\
8 & KLBF & 5,91 & 0,0045 & 0,45 \\
9 & MEDC & 184,83 & 0,1422 & 14,22 \\
10 & PTBA & 45,70 & 0,0352 & 3,52 \\
11 & UNVR & 27,36 & 0,0210 & 2,10 \\
12 & UNTR & 58,57 & 0,0451 & 4,51 \\
13 & SMGR & 21,95 & 0,0169 & 1,69 \\
14 & SRIL & 57,99 & 0,0446 & 4,46 \\
\hline Sumber: & data diolah, 2018 & &
\end{tabular}

Hasil perhitungan tabel 1. menggambarkan bahwa saham yang memiliki ratarata expected return tertinggi adalah saham MEDC yaitu $14,22 \%$ dan rata-rata expected retun terendah adalah saham ANTM yaitu $0,66 \%$.

Risko saham hanya dihitung untuk sampel yang memiliki expected return yang positif. Perhitungan Tabel 2. menunjukan bahwa saham dengan standar deviasi (risiko) tertinggi adalah MEDC yaitu 27,55\%, sedangkan saham yang memiliki standar deviasi terendah yaitu ICBP dengan nilai sebesar 3,74\%.

Kovarian positif mengindikasikan kemungkinan dua sekuritas bergerak ke arah yangsama, begitu sebaliknya. Kovarian nol berarti pergerakan dua sekuritas bersifat independen satu dengan yang lainnya.Korelasi antar saham ini diharapkan dapat mengurangi risiko dalam berinvestasi. Saham dengan korelasi negatif 
Ni Putu Eka Cahya Setyawati, Pembentukan Portofolio Optimal...

diharapkan mengurangi risiko secara efisien. Perhitungan kovarian dan korelasi antar saham menggunakan Microsoft Excel.

Tabel 2.

Standar Deviasi masing-masing Perusahaan dengan Expected Return Positif (\%)

\begin{tabular}{cccccc}
\hline No & $\begin{array}{c}\text { Kode } \\
\text { Saham }\end{array}$ & $\begin{array}{c}\text { Standar } \\
\text { Deviasi }\end{array}$ & No & $\begin{array}{c}\text { Kode } \\
\text { Saham }\end{array}$ & $\begin{array}{c}\text { Standar } \\
\text { Deviasi }\end{array}$ \\
\hline 1 & ADRO & 10,77 & 8 & KLBF & 4,62 \\
2 & ANTM & 15,83 & 9 & MEDC & 27,55 \\
3 & ASII & 4,09 & 10 & PTBA & 14,48 \\
4 & GGRM & 6,65 & 11 & UNVR & 4,29 \\
5 & HMSP & 5,27 & 12 & UNTR & 5,09 \\
6 & INDF & 4,18 & 13 & SMGR & 7,18 \\
7 & ICBP & 3,74 & 14 & SRIL & 14,04 \\
\hline
\end{tabular}

Sumber: data diolah, 2018

Menghitung return ekspetasian dan risiko portofolio dengan proporsi dana yang sama merupakan tahap keenam dalam pembentukan portofolio optimal. Proporsi awal dapat menggunakan asumsi bahwa proporsi seluruh saham dalam portofolio ini adalah sama sehingga masing-masing saham mendapatkan alokasi dana sebesar $7,14 \%$.

Berdasarkan Tabel 3. portofolio yang telah dibentuk oleh 14 saham tersebut memiliki proporsi yang sama sebesar 7,14\%, menghasilkan expected return 2,9\% dan tingkat risiko 4,6\%. Tahap ketujuh dalam pembentukan yaitumenghitung expected return dan risiko porotoflio dengan bobot dana yang optimal. Portofolio optimal dibentuk menggunakan Microsoft Excel dengan aplikasi program Solver. Program Solver membantu untuk menghitung besaran proporsi dana akhir pada masing-masing saham yang layak untuk di alokasikan. Berikut merupakan hasil 
dari expected return dan risiko portofolio setelah menggunakan aplikasi program Solver.

Tabel 3.

Expected Return dan Risiko Portofolio dengan Proporsi yang Sama

\begin{tabular}{|c|c|c|c|c|c|}
\hline No & $\begin{array}{c}\text { Kode } \\
\text { Saham }\end{array}$ & Proporsi & No & $\begin{array}{c}\text { Kode } \\
\text { Saham }\end{array}$ & Proporsi \\
\hline 1 & ADRO & $7,14 \%$ & 8 & KLBF & $7,14 \%$ \\
\hline 2 & ANTM & $7,14 \%$ & 9 & MEDC & $7,14 \%$ \\
\hline 3 & ASII & $7,14 \%$ & 10 & PTBA & $7,14 \%$ \\
\hline 4 & GGRM & $7,14 \%$ & 11 & UNVR & $7,14 \%$ \\
\hline 5 & HMSP & $7,14 \%$ & 12 & UNTR & $7,14 \%$ \\
\hline 6 & INDF & $7,14 \%$ & 13 & SMGR & $7,14 \%$ \\
\hline 7 & ICBP & $7,14 \%$ & 14 & SRIL & $7,14 \%$ \\
\hline \multicolumn{5}{|c|}{ Expected Return } & $2,9 \%$ \\
\hline \multicolumn{5}{|c|}{ Standar Deviasi } & $4,6 \%$ \\
\hline
\end{tabular}

Sumber: data diolah, 2018

Tabel 4.

Expected Return dan Risiko Portfolio dengan Proporsi dana yang Optimal

\begin{tabular}{|c|c|c|c|c|c|}
\hline No & $\begin{array}{c}\text { Kode } \\
\text { Saham }\end{array}$ & Proporsi & No & $\begin{array}{c}\text { Kode } \\
\text { Saham }\end{array}$ & Proporsi \\
\hline 1 & ADRO & $0,55 \%$ & 8 & KLBF & $0,00 \%$ \\
\hline 2 & ANTM & $0,00 \%$ & 9 & MEDC & $5,27 \%$ \\
\hline 3 & ASII & $0,15 \%$ & 10 & РTBA & $0,00 \%$ \\
\hline 4 & GGRM & $17,61 \%$ & 11 & UNVR & $41,11 \%$ \\
\hline 5 & HMSP & $0,00 \%$ & 12 & UNTR & $25,86 \%$ \\
\hline 6 & INDF & $0,00 \%$ & 13 & SMGR & $0,00 \%$ \\
\hline 7 & ICBP & $9,46 \%$ & 14 & SRIL & $0,00 \%$ \\
\hline \multicolumn{5}{|c|}{ Expected Return } & $3,2 \%$ \\
\hline \multicolumn{5}{|c|}{ Standar Deviasi } & $3,3 \%$ \\
\hline
\end{tabular}

Sumber: data diolah, 2018

Berdasarkan Tabel 4. diperoleh 7 saham menjadi anggota portfolio optimal, terdiri dari saham ADRO, ASII, GGRM, ICBP, MEDC, UNVR, dan UNTR dengan masing-masing proporsi dana yang diinvestasikan sebesar $0,55 \%, 0,15 \%, 17,61 \%$, 
Ni Putu Eka Cahya Setyawati, Pembentukan Portofolio Optimal...

$9,46 \%, 5,27 \%, 41,11 \%$, dan 25,86\%. Portoflio ini memberikan expected return sebesar 3,2\% dengan tingkat risiko sebesar 3,3\%.

Serangkaian perhitungan serta analisis pada penelitian, didapatkan hasil bahwa portofolio optimal yang dibentukk dengan menggunakan models Markowitz menghasilkan 7 buah saham yang layak menjadi anggota portofolio optimal. Program Solver yang diaplikasikann sangat membantu dalam penentuan proporsi dana yang optimal pada masing-masing saham. Tujuh buah saham yangmenjadi anggota portofolio optimal dengan proporsi alokasi dana masing-masing yaitu saham ADRO (0,55\%), ASII (0,15\%), GGRM (17,61\%), ICBP (9,46\%), MEDC (5,275), UNVR (41,11\%), dan UNTR (25,86\%), dan memberikan nilai expected return sebesar 3,2\% dan dengan tingkat risiko sebesar 3,3\% .

Investasi pada portfolio dengan proporsi dana yang sama besarnya bila di bandingkan dengan investasi pada portofolio dengan proporsi dana yang optimal, memiliki perbedaan yang terletak pada beban tingkat risiko dan besarnya expected return yang bisa diperoleh investor. Dengan dibntuknya portofolio maka expected return yang diperolah investor meningkat sebesar $0,3 \%$. Besarnya tingkat risiko yang ditanggung oleh investor menurun sebesar 1,3\%. Hal ini menjelaskan bahwa dengan adanya bantuan program solver dalam membentuk portofolio dengan proporsi dana yang optimal, menghasilkan tingkat return ekspetasian yang lebih besar ( meningkat) dengan tingkat risiko yang nilainya lebih kecil (menurun). Hal ini tentunya akan sangat membantu para investor untuk memilih saham-saham ketika akan berinvestasi pada saham perusahaan sektor pertambangan dan barang 
konsumsi.Perbedaan expected return serta risiko portofolio dengan saham-saham individual lainnya dapa dilihat pada gambar berikut ini:

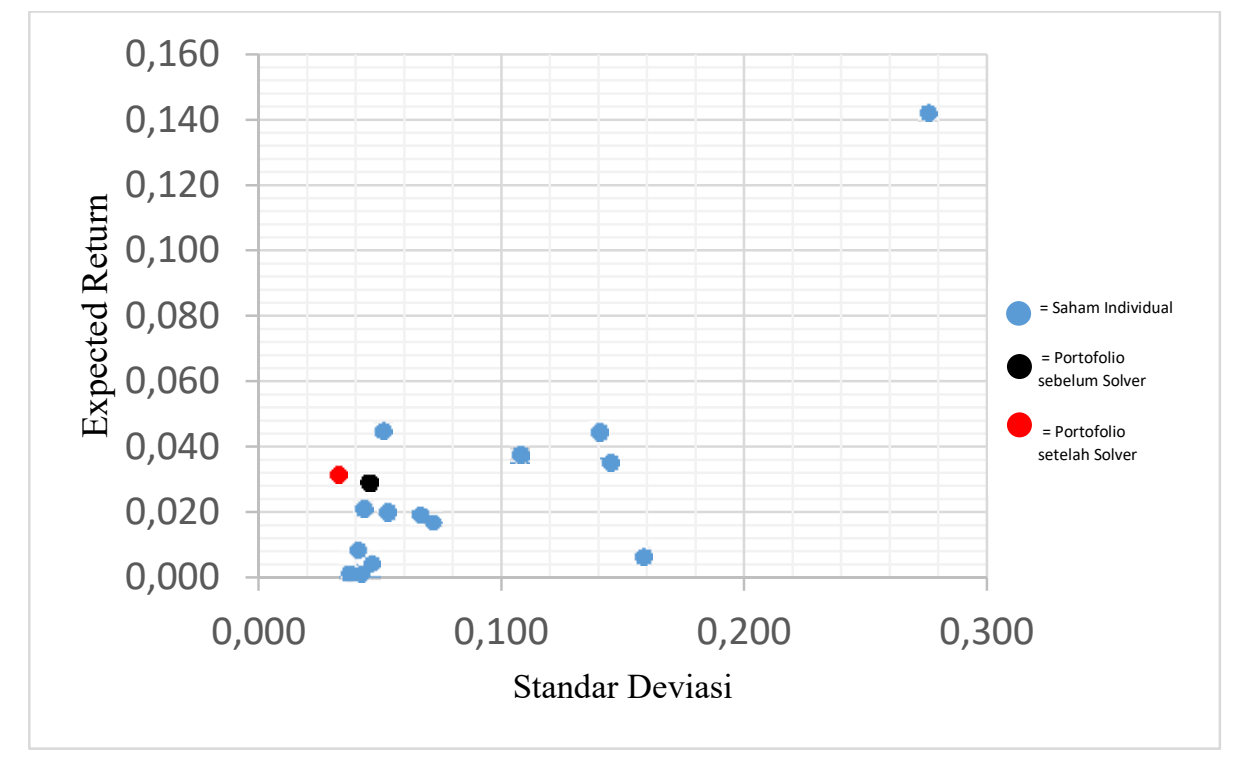

Gambar 1. Expected Return dan Risiko antara Saham Individual dengan Portofolio

Sumber : data diolah, 2018.

Berdasarkan Gambar 1 dapat dilihat perbedaan tingkat keuntungan dan risiko antara saham individual dengan saham portofolio. Pada portfolio yang terbentuk, portofolio memberikan hasil kombinasi aset dengan tingkat risiko terrendah, hal ini mengindikasikan bahwa investasi dengan membentuk sebuah portofoio dapat mengurangi risiko dalam suatu investasi dibandingkan hanya berinvestasi pada satu jenis aset.

Hasil penelitian menunjukkan bahwa portofolio yang terbentuk sebagai bentuk dari diversifikasi investasi terbukti dapat membantu mengurangi risiko investasi. Hasil penelitian menunjukkan bahwa portofolio yang terbentuk mampu menghasilkan tingkat pengembalian (return) yang maksimal dengan tingkat risiko tertentu yang sesuai dengan harapan investor. Program solver yang digunakan 
Ni Putu Eka Cahya Setyawati, Pembentukan Portofolio Optimal...

semakin membantu investor dalam menentukan pilihan berivestasi untuk memeroleh return dan risiko yang sesuai dengan harapan mereka.

\section{SIMPULAN DAN SARAN}

Penentuan portofolio optimal menggunakan model Markowitz periode Januari 2017 - Januari 2018 terpilih tujuh saham perusahaan yang menjadi kandidat portofolio. Sektor pertambangan terpilih dua saham perusahaan, sedangkan pada sektor barang konsumsi terpilih sebanyak lima perusahaan. Perusahaan sektor pertambangan terpilih adalah Adaro Energy Tbk dan Medco Energi Internasional Tbk , pada sektor barang konsumsi yaitu Astra Internasional Tbk, Gudang Garam Tbk, Indofood CBP Sukses Makmur Tbk, Unilever Indonesia Tbk, dan United Tractors Tbk .

Besar proporsi dana saham perusahaan yang layak menjadi anggota portofolio optimal masing-masing yaitu ADRO (0,55\%), ASII (0,15\%), GGRM (17,61\%), ICBP (9,46\%), MEDC (5,275\%), UNVR (41,11\%), dan UNTR $(25,86 \%)$. Pembentukan portofolio optimal ini dibantu dengan program solver pada Microsoft Excel, terdapat perbedaan besaran expected return dan risiko pada portofolio saham sebelum menggunakan solver dengan portofolio saham setelah menggunakan solver. Portofolio saham sebelum menggunakan solver memiliki expected return sebesar $2,9 \%$ dan risiko $4,6 \%$, kemudian setelah dianalisis menggunakan solver, expected return meningkat menjadi 3,2\% dan risiko menurun menjadi $3,3 \%$.

Investor yang ingin berinvestasi pada portofolio saham, diharapkan tidak hanya menginvestasikan dana yang ada pada satu jenis saham melainkan disebar 
dengan melakukan diversifikasi . Dana yang dimiliki investor diharapkan dapat tersebar pada aset-aset yang memang memberikan return serta risiko sesuai harapan dan preferensi investor.

Para Investor yang tertarik berinvestasi pada Indeks IDX 30, dapat menginvestasikan dana yang ada sesuai dengan rekomendasi portfolio optimal yang terbentuk dari saham-saham ADRO dengan proporsi dana 0,55\%, ASII dengan proporsi dana $0,15 \%$, GGRM dengan proporsi dana 17,61\%, ICBP dengan proporsi dana 9,46\%, MEDC dengan proporsi dana 5,275\%, UNVR dengan proporsi dana 41,11\%, dan UNTR dengan proporsi dana 25,86\%.

Portofolio ini memberikan tingkat pengembalian sebesar 3,2\% dan tingkat risiko sebesar 3.3\%. Perubahan-perubahan situasi yang diakibatkan oleh faktor dari dalam maupun luar perusahaan dapat mempengaruhi perkembangan saham sewaktu-waktu. Investor disarankan untuk selalu melakukan pengawasan karena portofolio ini tidak selamanya menjadi portofolio yang optimal.

Peneliti selanjutnya yang akan melakukan penelitian sejenis dapat menggunakan lebih banyak sektor dalam pembentukan portofolio optimal agar investor memiliki lebih banyak pilihan berinvestasi. Penggunaan berbagai metode lainnya juga akan membantu dalam pembentukan portofolio optimal yang lebih bervariasi. Penelitian selanjutnya diharapkan dapat membandingkan metode Markowitz dengan metode lainnya untuk mengetahui apakah terdapat perbedaan hasil apabila sebuah portofolio dibentuk dengan metode yang berbeda. 


\section{REFERENSI}

Abdurrazak, Muhammad. (2017). Implementasi Metode Markowitz dalam Pemilihan Portofolio Saham Optimal. Jurnal Matematika dan Statistika serta Aplikasinya, 5(2): 34-69

AJ Du Plessis dan M. Ward. (2009). A note to applying the Markowitz portfolio, selections model passive investment strategy on the JSE. Investment Analysts Journal. 6(9): 39-46.

Bekhet, dan Ali Matar. (2012) . Risk Adjusted Performance: An Approach Application in Amman Stock Exchange. International Journal of Business and Social Science. 3(6): 34-45

Chandra , Liliana dan Yudith Dyah Hapsari. (2013). Analisis Pembentukan Portofolio Optimal dengan menggunakan Model Markowitz pada Saham LQ 45 Periode 2008-2012. Jurnal Manajemen. 1(2): 41-65.

Gogajeh, Khoshnevis dan Asghar Salahi Bonab. (2015). Compare Ability of Markowitz, Single Index Model of Sharp, Data Envelopment Analysis and Value at Risk Models in Selecting Optimum Portfolio of Stocks in Accepted Companies of Tehran Stock Exchange. MAGNT Research Report. 3(1): 1286-129

Hartono, Jogiyanto. (2016) . Teori Portofolio dan juga Analisis Investasi. Edisi Kesepuluh. Yogyakarta : BPFE

Salemba Empat.

(2014). Teori Dan Praktik Portofolio dengan Excel. Jakarta:

Indrayani. (2013). Penentuan Portfolio Optimal dengan Model Markowitz pada Saham Perbankan di Bursa Efek Indonesia. E-Jurnal Manajemen Universitas Udayana. 2(8): 869-884

Ivanova, M. (2017) . ApplicationMarkowitz Portofolio Optimization on Bulgarian Stock Market from 2013 to 2016. International Journal of Pure and Apllied Mathematics, 117(2): 291-308

Kamil, Fei, dan Lee Kinn Kok. (2006) . PortfolioAnalysis using Markowitz Model. Journal of Statistics and Management Systems. 9 (3) : 519-537.

Lee, Hui Shan, Cheng Fan Fah dan Chong Shyue Chuan. (2015). Markowitz Portfolio Theory and Capital Asset Pricing Model for Kuala Lumpur Stock Exchange. International Journal of Economics and Financial Issues, 6(12): 59-66. 
Marasovic, Poklepovic, dan Zdravka Aljinovic. (2011). Markowitz Model Fundamental and Technical Analysis - Complementary Methods or Not. Croatian Operational Research Review (CRORR ), 1(2): 122-131.

Makwe, Duruechi, dan Josephine N. Ojiegbe. (2016). Markowitz and a Naive Approaches to Portfolio Analysis (An Empirical Analysis of Some Selected Securities Quoted on the Nigerian Stock Exchange). Research Journal of Finance and Accounting, 7(2): 108-124.

Mokta . (2013) . Markowitz Portfolio Model : Evidence from Dhaka Stock Exchange in Bangladesh India, IOSR Journal of Business and Management, 8(6): $68-73$.

Nalini ,R. (2014). Optimal Portofolio Construction Using Markowitz Model-A Study of Selected Stocks From BSE. International Journal of Advanced Research in Management and Social Sciences, 3(12): 72-94.

Natalia, dkk. (2012). Penentuan Portofolio Saham yang Optimal dengan Model Markowitz sebagai Dasar Penetapan Investasi Saham. Jurnal Administrasi Bisnis, 6(1): 1-9.

Parmar, Chetna. (2015) . Portofolio Selection using Markowitz Model on Selected Sectors Companies in India. International Multidisciplinary Research Journal, 2(12): 1-6.

Pracanda, Sinta Putri. (2017) . Pembentukan Portofolio Optimal dengan menggunakan Model Markowitz Saham Indeks IDX 30 studi kasus diBursa Efek Indonesia. E-Journal Manajemen Universitas Udayana, 6(2): 802829.

Rahmat , Doddy dan Budi Nugroho. (2013). Portofolio Determination and Markowitz Models Efficient Frontier in Five Indonesian Industrial Sector. Journal of Business and Management, 2(1): 116-131.

Ramadhan, Handayani dan Maria Goretti Wi Endang. (2014). Analisis Pemilihan Portofolio Optimal dengan Model dan Pengembangan dari Portofolio Markowitz (Studi pada Indeks BISNIS-27 di Bursa Efek Indonesia periode 2011 - 2013). Jurnal Administrasi Bisnis (JAB), 14(1): 1-10.

Rodrigues, Joel Allen dan Suresha B. (2018). A Study on Risk and Return in Building Optimal Portfolio using Markowitz Models and Its Relevance in Current Ratio. International Journal of Advanced Research and Development. 3(2): 196-200. 
Saranya, Prasanna dan Krishna . (2014) . Optimal Portfolio Selection and Optimization with Higher Moments : Evidence from the Indian Stock Market. Asia-Pacific Finan Markets, 21(2): 133-149.

Sarker, Mokta Rani. (2013). Markowitz Portfolio Model: Evidance from Dhaka Stock Exchange in Bangladesh. IOSR Journal of Business and Management. 8(6): 68-73.

Setiawan, Andika . (2015). Analisis Pembentukan Portoflio yang Efisien dengan menggunakan Model Markowitz pada Perusahaan Asuransi di Indonesia. Naskah Publikasi. Universitas Muhammadiyah Surakarta Online Journals, 1(6): $1-16$

Sudiman, Josephine dan Elsa Novyana. (2016). Pembentukan Portofolio Optimal Menggunakan Model Markowitz. National Conference of Applied Sciences, Engineering, Business and Information Technology, 3(10): 211-216

Tandelilin, Eduardus (2010) . Portofolio dan Investasi . Edisi Pertama. Yogyakarta : Kanisius.

Wijayanto , Andi. (2015). Analisis Perbedaan terkait Return dan Risiko Saham Portfolio Optimal dengan Bukan Portofolio Optimal. Management Analysis Journal, 4(1): 1-9.

Yunita, Irni. (2017). Markowitz Models dalam Aplikasi Pembentukan Portofolio Optimal. Jurnal Manajemen Indonesia, 18(1): 77-84. 